\title{
Prevalence and Burden of Gastrointestinal Parasites in Stray Cattle of Kathmandu Valley
}

\section{Bigyan Thapa}

Tribhuvan University Institute of Science and Technology

Rajendra Prasad Parajuli

Tribhuvan University Institute of Science and Technology

Pitambar Dhakal ( $\square$ pitambar.dhakal@cdz.tu.edu.np)

Tribhuvan University Institute of Science and Technology https://orcid.org/0000-0003-3977-9085

\section{Research Article}

Keywords: Straycattle, calves, heifers, gastrointestinal parasites, prevalence, Kathmandu

Posted Date: January 3rd, 2022

DOI: https://doi.org/10.21203/rs.3.rs-1184271/v1

License: @ (i) This work is licensed under a Creative Commons Attribution 4.0 International License. Read Full License 


\section{Abstract}

Gastrointestinal parasites (GIPs) are ubiquitous among cattle resulting severe infection. Prevalence of GIPs in stray street cattle may pose risk of dissemination of parasites of zoonotic importance. This study was conducted to determine the prevalence of GIPs in stray cattle of Kathmandu valley. Hundred $(n=100)$ freshly voided dung samples were collected from eight places. The samples were processed using concentration method for microscopic examination, and modified McMaster technique for quantification of mean eggs/oocysts per gram of feces (EPG/OPG). Results revealed that $72 \%$ of the cattle were found positive for one or more species of GIPs and nine genera of GIPs were recorded (Eimeria, Ostertagia, Haemonchus, Trichostrongylus, Capillaria, Trichuris, Toxocara, Fasciola and Paramphistomum). The prevalence of parasitic infection was higher in male (73.68\%) than in female (69.76\%). The prevalence was found to be highest in adults $(63.89 \%)$ followed by heifers $(27.78 \%)$ and calves $(8.33 \%)$. Approximately $76 \%$ of the cross breed and $65 \%$ local breed of cattle were positive for parasitic infection. The parasites differed both in prevalence and intensity, Eimeria sp. being the most prevalent (27\%) with highest intensity (858.02 OPG $\pm 63.46 \mathrm{SD}$ ). To our information, this is the first research of its kind in relation to stray cattle in Nepal. Our findings reveal that there is burden of helminth infections of zoonotic and socioeconomic importance in the straycattle. Therefore, it warrants regular inspection, relevant preventive measures and molecular detection of parasites.

\section{Introduction}

One of the major impediments for commercial livestock production in tropical and subtropical countries is intestinal parasitic infections (Hoste et al. 2006; Kakar et al. 2008). Almost all ages of cattle are infected by a variety of groups of intestinal parasites, however the mortality associated with it is very less. The gastrointestinal parasites (GIPs) cause reduced weight gain, digestive disturbances, lowered production, impaired reproductive performance, mortality (Raza et al. 2007). Reduced output of animal products, by products, manure and traction directly affect in the role of cattle in ensuring food security most particularly in developing countries (Rajakaruna and Warnakulasooriya 2011).

The problems posed by gastrointestinal parasitism are often neglected and overlooked since most of the infected cattle show little obvious sings during their reproductive life however the effects are gradual and chronic (Raza et al. 2010). The most important predisposing factors of helminth infestation in cattle are grazing habits (Brito et al. 2013), climate (Fox et al. 2012), nutritional deficiency (de Gier et al. 2014), pasture management (De Mendonca et al. 2013), immunological status (Mabbott 2018; Weatherhead et al. 2020), presence of vector (Otranto et al. 2013), intermediate host (Chubb et al. 2010), the number of infective larvae and eggs in the environment (Adedipe et al. 2014). Favorable environmental condition such as temperature, humidity and several others play an important role for the growth of GIPs, and grasslands are one of the main sources of gastrointestinal parasitic diseases to animals (Mondal et al. 2000) from where parasites get transmitted to one another by fecal-oral route. The parasites of the digestive system particularly small intestine and large intestine infest grazing animals (Taylor et al. 2007). Therefore, grazing land play important role to make animal healthy. In general, younger animals and animals under stress are most likely to show signs of parasitism (Sahoo et al. 2002).

Rampant movement of stray cattle in the streets and other public places mostly around temples, under bridges, around the river banks and even in the main road are a common observation in Kathmandu valley. Prevalence of GIPs in stray street cattle may pose risk of dissemination of parasites of zoonotic importance. Therefore, this research was conducted to determine the prevalence and intensity of gastrointestinal parasites along with suceptability of groups (i.e., local $v s$ cross breed or male $v s$ female or calves $v s$ heifer $v s$ adult) in stray cattle of Kathmandu valley.

\section{Materials And Methods}

\section{Study area}

Kathmndu district is located in Bagmati province (Fig.1) with an area of $395 \mathrm{~km}^{2}$ and 1,744,240 inhabitants (NPHC 2011). Kathmandu valley is the capital and largest city of Nepal standing at an altitude of 1400 masl, characterized by moderately hot during March to April. The maximum temperature varied from $25.3^{\circ} \mathrm{C}$ to $28.2^{\circ} \mathrm{C}$ and minimum $8.2^{\circ} \mathrm{C}$ to $11.7^{\circ} \mathrm{C}$, and the relative humidity varied from $53 \%$ to $61 \%$ during the study period (Anonymous 2019 ).

\section{Methods}

Page 2/11 


\section{Sample collection and preservation:}

The minimum sample size for this study was determined by using Thrusfield (2005) formula. Ethical approval was obtained from Tribhuvan University, animal welfare policy was strictly followed and the cattle were not harmed by any means. During March to April, 2019, 100 fresh dung samples (approximately 5-10gm from each animal) were collected from eight locations immediately after defecation using sterilized wooden applicator, stored in plastic container with $2.5 \%$ potassium dichromate as preservative and labeled with specific identification number. While sampling the cattle were classified as calf (0-1 years), heifer (1-3 years), adult ( $₫ 3$ years), local breed and cross breed with the aid of trained veterinary technician. The collected samples were immediately fetched to the Parasitology Laboratory of Central Department of Zoology, Tribhuvan University and stored at $4^{\circ} \mathrm{C}$ until examination.

\section{Questionnaire survey}

Questionnaire survey was conducted among forty people generally vendors, local shopkeepers, street shop owners in and around the sampling area. It mainly included queries regarding the total number of roaming cattle in the sampling spot, their regular place of living, approximate distance travelled for finding food and water, types of food materials, sources of water, chances of food being supplied by local people and mixing up with other stray animals.

\section{Identification and quantification of GIPs}

Qualitative procedures like normal saline and iodine wet mount, flotation and sedimentation techniques were used with slight modification. At least, two smears were prepared from each sample for each technique to identify eggs and oocysts based on their morphological characters (Soulsby 1982; Foreyt 2001; Taylor et al. 2007; Zajac and Conboy 2011). The size of coccidian oocysts and helminth eggs were measured using calibrated ocular micrometer under 400x magnification and compared with the available data (Foreyt 2001; Zajac and Conboy 2012). Parasite positive faecal samples were subjected to McMaster technique with slight modification to quantify the eggs/oocysts per gram (EPG/OPG) of faecal sample (Levecke et al. 2011). The degree of infection was classified as light (50-799EPG/OPG), moderate (800-1200EPG/OPG) and higher (>1200EPG/OPG) according to Urquhart et al. (1994).

\section{Data analysis}

The data were entered into the MS-Excel 2010 and statistical analysis was performed using "R", version 3.5 .2 software package with Chi-squared test to compare the differences between the groups, and mean values were compared by Duncan's multiple range test (DMRT). In all cases $95 \%$ confidence interval $(\mathrm{Cl})$ and $\mathrm{p}<0.05$ was considered for statistically significant association.

\section{Results}

\section{Prevalance of GIPs}

Of the one hundred samples examined, $72 \%$ cattle were found to be positive for one or more GIPs. A total of nine genera of parasites were identified. Eimeria (27\%) with highest prevalence was the only parasite witnessed among protozoans. Among nematodes, Ostertagia (9\%) had the maximum prevalence followed by Haemonchus (7\%), Trihcostrongylus (5\%), Capillaria (3\%), Strongyle-type (3\%), Trichuris (2\%) and Toxocara 1\% (Table 1). Similarly, Fasciola (11\%) and Paramphistomum (4\%) were observed among trematodes, and none of the cestodes were recorded. The photographs of the identified coccidian oocysts and helminth eggs have been illustrated (Fig. 2).

The results revealed that the parasite prevalence was higher in male(73.68\%) than in female(69.76\%), but there was no statistical significance ( $p>0.986$ ) (Table 2).Prevalence of GIPs was recorded to be $8.33 \%, 27.78 \%$ and $63.89 \%$ in calves, heifers and adultsrespectively (Table 3). The prevalence was statistically significant $(p<0.025)$ in relation to the age of stray cattle. Regarding breed-wise analysis of GIPs prevalence, $64.86 \%(n=24)$ of local breeds and 76.19\% $(n=48)$ of cross breeds revealed positive result for parasitic infection (Table 2). There was no statistical significant association of infection between local breeds and cross breeds ( $p=$ 0.738).

Area-wise prevalence of GIPs shows that highest percentage was observed in Kirtipur area (83.33\%) followed by Kalanki (80\%) and Gaushala (73.33\%). Eimeria was recorded in all the sampling sites with its highest prevalence in Budhanilkantha (42.85\%). None of the trematodes were recorded from Budhanilkantha and Naksal area (Table 4). 


\section{Single and mixed infection of GIPs}

Out of 72 cattle shedding parasite oocysts and/or eggs, 36.11\% $(n=26)$ were infected with single parasites where Fasciola was dominant, and $68.89 \%(n=46)$ had mixed infection which consisted of Eimeria plus Fasciola being the most common. Among mixed infection, a great majority of cattle had duplet infection (86.95\%) where the association of Eimeria was maximum followed by Fasciola, and minority (13.04\%) had triplet infection (Table 5).

\section{Intensity of GIPs}

Approximately $58 \%$ of the stray cattle were found to have lower, $33 \%$ moderate and only $8 \%$ higher level of infection of GIPs. The higher intensity of infection was noticed only for Eimeria, and helminths had lower to moderate intensity. The highest mean OPG (858.02 \pm 63.46$)$ was recorded in Eimeria while among the nematodes, Capillaria had the highest mean EPG (544.44 \pm 19.24$)$, Haemonchus and Trichuris had almost same mean EPG, and among trematodes Fasciola had highest mean EPG $(408.33 \pm 62.51)$ (Table 1).

\section{Behavioral observation of stray Cattle}

The questionnaire survey and field observation have provided us some important information. The stray cattle did not have a fixed location as they were often witnessed moving for a long distance for finding food and water, and some of them were even found travelling more than $5 \mathrm{~km}$ distance. They generally rely on vegetable garbage thrown from the vegetable markets and leftover food available along with other wastes. They also graze along the river banks and other open fields along the road side. Sometimes, they are also fed by the local people, pedestrians, pilgrims, and restaurant owners. Great majority of the stray cattle take rest during day and night under bridges, some under the small sheds or tents outside the shop most often accompanied by the stray dogs, and others are found in the open places along the road side, river and wherever possible even during sweltering hot summer days and the time of heavy rain fall.

\section{Discussion}

The finding of our study revealed that $72 \%$ of the stray cattle roaming at various regions in Kathmandu valley had burden of gastrointestinal parasite infection which is in agreement with prevalance of gastrointestinal parasites in cattle and buffaloes in Jabalpur, India (Markole et al. 2016) and 75.46\% from Bangladeshreported by llyas et al. (2016). Yet, prevalance observed in our study was quite lower than $95.5 \%$ prevalence reported from Southern Ghana (Squire et al. 2013), 86.9\% prevalence among dairy cattle reported from Taiwan (Huang et al. 2014) and 84.8\% prevalence reported from Dhaka, Bangladesh (Rashid et al. 2015). In contrast, Jittapalapong et al. (2011) and Gunathilaka et al. (2018) have reported relatively lower prevalence in domesticated cattle managed in intensive farms at the rate of $46.6 \%$ and $11.56 \%$, respectively. This variation in finding might be due to the difference in the number of fecal sample examined from free ranging and semi-intensive cattle,season of sampling and climatic condition of the study area. Similar type of prevalence study was reported by Shirale et al. (2008), Marskole et al.(2016), Takeet et al. (2016) and Dogo et al. (2017).

Fasciola was found to have highest prevalence (11\%) among all the helminth parasitesrecorded. However, nematode topped the overall prevalence (30\%) followed by Eimeria (27\%) and trematodes $(15 \%)$. The overall prevalence of fascioliasis was $51 \%$ in cattle examined in Mahottari and Dhanusha (Yadav et al. 2015). Based on molecular phylogenetic analysis Fasciola flukes have been reported from eight districts of Nepal including Bhaktapur and Kavrepalanchok (Shoriki et al. 2014). Our finding is worth comparing with Choubisa and Jaroli (2013) who reported $15.18 \%$ prevalence of Fasciola spp. in various domestic ruminants and $18.46 \%$ in cattle. The prevalence of Fasciola spp. was higher (16.67\%) than that of Paramphistomum spp. (9.37\%) in yak in lower Mustang, Nepal (Acharya et al. 2016) while Maitra et al. (2014) recorded 12.4\% prevalence of various species of paramphistomes in domestic ruminants. The prevalence of trematodes in our study is remarkable, but there is not much information regarding the presence of suitable intermediate molluscan hosts for larval development in our study area. It might be because the stray cattle may have harbored such flukes for a long time since when the cattle were taken by the farmers. The overall prevalence of helminth infection (46\%) noted in this study is almost closer to that of Adedipe et al. (2014) while it differs from those reported by Leon et al. (2019) who found 22.3\% prevalence of Fasciola and $16.5 \%$ of strongylid nematodes with $17.4 \%$ of Eimeria. Heidari et al. (2014) reported nine species of Eimeria with overall infection rate of $8.25 \%$. A very high prevalence of Eimeria (94.7\%) was reported from dairy cattle in Costa Rica (Jimenez et al. 2007) while it was lower among the female cattle in Bali, Indonesia (Indraswari et al. 2017). Such variations may be attributed

Page $4 / 11$ 
to the anthelminthic treatment history, body conditions of cattle and management system (Bacha and Haftu 2014). But in our study there is neither record of anthelmintic treatment nor other previous information as all the stray cattle were sampled from various sites where they were found gathered, roaming, and feeding whatever was available. This might also cause variation in the prevalence of GIPs in cattle. Our study has recorded Toxocara, a common worm found in canine and feline hosts, in one of the cattle. This might be the consequence of their close association with dogs, and probable dog-faecal contamination to the cattle food.

The overall gastro-intestinal parasitic infection was similar between male and female cattle. This result is in concordance with Marskole et al. (2016) and Maharana et al. (2016). Male and female grazing on the same grass land or forest, sharing the same shed and supplied with same grains and grass, that might have provided equal chance of transmission of any parasitic diseases (Bacha and Haftu 2014). The prevalence rate of GIPs regarding age-wise classification in calves (43\%), heifers (76\%) and adults (77\%) appears to be similar (i.e., rate of infection growing with growing age) to that of Bacha and Haftu (2014) as both have similar study design. Similarly, the higher prevalence recorded in the adult cattle could be the result of their prolonged exposure to the infective stages of GIPs. We have also noticed more mixed infections than single infection among older cattles. The younger cattlewere characterized by the presence of majority of duplet infection than triplet. The mixed infection has been considered to be a main cause of morbidity and reduced production from the livestock (Bersissa et al. 2011) and at the same time it accelerates the host susceptibility to other parasitic infections (Wang et al. 2006).

The quantification of parasite egg and oocysts is generally performed in order to determine the extent of pasture contamination by the infected animals while grazing, to access the efficacy of drug treatment and for examination of drug resistance (Zajac and Conboy 2012). Realizing the same fundamental principle, we also quantified the protozoan oocysts and helminth eggs per gram of faecal sample. Leon et al. (2019) documented similar range of OPG for Eimeria (820-1270) which was more or less closer to our findings. Wadhwa et al. (2011) reported EPG for strongyle species ranging between 200-1000 with an average of 504 \pm 245.41 in cattle which is comparable to our findings. Contrary to our results, Laha et al. (2013) recorded higher the mean EPG in nematodes (50-4000) and OPG for coccidian parasites (50-1400). In relation to the mild climate of Kathmandu valley, absence of parasite control programs in the stray cattle, continuous movement of cattle and taking food whatever available and grazing in the open places, the mean EPG in case

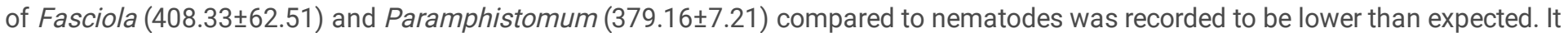
might be attributed to the type of floatation solution as the trematode eggs are heavier than that of nematodes. The reliability and efficiency of the quantification of parasite eggs depends on the amount of faeces examined (Mes et al. 2001), the floatation solution used, dilution ratio and the McMaster slide area (volume) examined (Cringoli et al. 2004), yet our method (i.e., 5 gram sample with concerntration method) should not allow such situation.

\section{Conclusion}

This study revealed relatively high (compared to domesticated) but modarate prevalence of gastrointestinal protozoan and helminth parasites in the stray cattle with low to moderate level of infection intensity. Each sampling site represented at least one or more types of GIPs. The quantified EPG/OPG also suggests that there is higher chance of contamination of soil which may result in the transmission of zoonotically important parasites. Therefore, to mitigate the cattle borne parasite burden, public awareness, proper management of the street cattle, administration of anthelmintics and other relevant control measures need to be underlined.Further studies are relevant at the molecular level which will provide obvious evidences of the zoonotic potential of the parasite and therefore, it would provide way forward to take necessary steps for preventive measures.

\section{Declarations}

\section{Ethical Consideration}

No animals were harmed during this research work.

\section{Competing interests}

The authors declare that they have no conflict of interest.

\section{Funding}

This research did not receive any specific grant from funding agencies in the public, commercial, or not-for-profit sectors. 
BT: Conceptualization, Methodology, Investigation, Software, and Writing-Original draft preparation. RPP: Conceptualization, Methodology, Writing-Reviewing. PD: Conceptualization, Methodology, Supervision, Investigation and Writing-Reviewing and Resources.

\section{References}

1. Acharya KP, Nirmal BK, Kaphle K, Mahato MK, Yadav GP, Rana, HB (2016) Prevalence of gastrointestinal and liver parasites in yaks in the cold desert area of lower Mustang, Nepal. Asian Pac J Trop Dis 6(2), 147-150. https://doi.org/10.1016/S22221808(15)61001-5

2. Adedipe OD, Uwalaka EC, Akinseye VO, Adediran, OA, Cadmus, SIB (2014) Gastrointestinal helminths in slaughtered cattle in Ibadan, south-Western Nigeria. J Vet Med 4:123-132. https://doi.org/10.1155/2014/923561

3. Bacha A, Haftu B (2014) Study on prevalence of gastrointestinal nematodes and coccidian parasites affecting cattle in West Arsi zone, Ormia Regional State, Ethiopia. J Vet Sci Technol 5:207

4. Bersissa K, Tigist T, Teshale S, Reta D, Bedru H (2011). Helminths of sheep and goats in central Oromia (Ethiopia) during the dry season. Journal of Animal and Veterinary advances, 10(14), 1845-1849. https://doi.org/10.3923/javaa.2011.1845.1849

5. Brito DL, Dallago BSL, Louvandini H, Santos VRVD, Torres SEFDA, Gomes EF, Amarante AFTD, Melo CBD, McManus CM (2013) Effect of alternate and simultaneous grazing on endoparasite infection in sheep and cattle. Rev Bras Parasitol Vet 22:485494. https://doi.org/10.1590/S1984-29612013000400007

6. Choubisa SL, Jaroli VJ (2013) Gastrointestinal parasitic infection in diverse species of domestic ruminants inhabiting tribal rural areas of southern Rajasthan, India. J Parasit Dis 37:271-275. https://doi.org/10.1007/s12639-012-0178-0

7. Chubb JC, Ball MA, Parker GA (2010). Living in intermediate hosts: evolutionary adaptations in larval helminths. Trends Parasitol 26:93-102. https://doi.org/10.1016/j.pt.2009.11.008

8. Cringoli G, Rinaldi L, Veneziano V, Capelli G, Scala A (2004) The influence of flotation solution, sample dilution and the choice of McMaster slide area (volume) on the reliability of the McMaster technique in estimating the faecal egg counts of gastrointestinal strongyles and Dicrocoelium dendriticum in sheep. Vet Parasitol 123:121-131. https://doi.org/10.1016/j.vetpar.2004.05.021

9. de Gier B, Campos Ponce M, van de Bor M et al (2014) Helminth infections and micronutrients in school-age children: a systematic review and meta-analysis. Am J Clin Nutr 99:1499-1509. https://doi.org/10.3945/ajcn.113.069955

10. De Mendonca RMA, Leite RC, Lana AMQ et al (2014) Parasitic helminth infection in young cattle raised on silvopasture and openpasture in Southeastern Brazil. Agroforestry Systems88:53-62. https://doi.org/10.1007/s10457-013-9655-4

11. Anonymous (2019) Department of Hydrology and Meteorology, Government of Nepal, Ministry of Energy, Water Resources and Irrigation

12. Dogo GIA, Karaye PG, Patrobas MG et al(2017) Prevalence of gastrointestinal parasites and their impact in domestic animals in Vom, Nigeria. Saudi J Med Pharm Sci 3:211-216

13. Foreyt WJ (2001) Veterinary parasitology reference manual. Blackwell Publishing, USA.

14. Fox NJ, Marion G, Davidson RS et al (2012) Livestock helminths in a changing climate: approaches and restrictions to meaningful predictions. Animals 2:93-107. https://doi.org/10.3390/ani2010093

15. Gunathilaka N, Niroshana D, Amarasinghe D et al (2018) Prevalence of gastrointestinal parasitic infections and assessment of deworming program among Cattle and Buffaloes in Gampaha District, Sri Lanka. BioMed Res Int 18:1155.https://doi.org/10.1155/2018/3048373

16. Heidari H, Sadeghi-Dehkordi Z, Moayedi R (2014) Occurrence and diversity of Eimeria species in cattle in Hamedan province, Iran. Vet Med 59:271-275. https://doi.org/10.17221/7570-VETMED

17. Hoste H, Jackson F, Athanasiadou S et al (2006) The effects of tannin-rich plants on parasitic nematodes in ruminants. Trends Parasitol 22:253-261. https://doi.org/10.1016/j.pt.2006.04.004

18. Huang CC, Wang LC, Pan CH et al (2014) Investigation of gastrointestinal parasites of dairy cattle around Taiwan. J Microbiol Immunol Infect 47:70-74. https://doi.org/10.1016/j.jmii.2012.10.004

19. Ilyas N, Hossain MM, Bhuyan MJU et al (2016) Prevalence of Gastro-intestinal Nematodes Infection of Cattle in Bangladesh. AJPCT 4:091-097

Page 6/11 
20. Indraswari AAS, Suwiti NK, Apsari IAP (2017) Eimeria auburnensis and Eimeria bovis of protozoa gastrointestinal infected on female Bali cattle in Nusa Penida. Buletin Veteriner Udayana 9:112-116.

21. Jiménez AE, Montenegro VM, Hernández J et al (2007) Dynamics of infections with gastrointestinal parasites and Dictyocaulus viviparus in dairy and beef cattle from Costa Rica. Vet Parasitol 148:262-271. https://doi.org/10.1016/j.vetpar.2007.06.015

22. Jittapalapong S, Sangwaranond A, Nimsuphan B et al (2011) Prevalence of gastro-intestinal parasites of dairy cows in Thailand. Kasetsart J (NatSci) 45:40-45

23. Kakar MN, Kakarsulemankhel JK (2008) Prevalence of endo (trematodes) and ecto-parasites in cows and buffaloes of Quetta, Pakistan. Pak Vet J 28:34

24. Laha R, Das M, Goswami A (2013) Gastrointestinal parasitic infections in organized cattle farms of Meghalaya. Vet World 6:109. https://doi.org/10.5455/vetworld.2013.109-112

25. León JCP, Delgado NU, Florez AA (2019) Prevalence of gastrointestinal parasites in cattle and sheep in three municipalities in the Colombian Northeastern Mountain. Vet World 12:48. https://doi.org/10.14202/vetworld.2019.48-54

26. Levecke B, Behnke JM, Ajjampur SS et al (2011) A comparison of the sensitivity and fecal egg counts of the McMaster egg counting and Kato-Katz thick smear methods for soil-transmitted helminths. PLoS Negl Trop Dis 5:e1201. https://doi.org/10.1371/journal.pntd.0001201

27. Mabbott NA (2018). The influence of parasite infections on host immunity to co-infection with other pathogens. Front Immunol 9:2579. https://doi.org/10.3389/fimmu.2018.02579

28. Maharana BM, Kumar BR, Sudhakar NR et al (2016) Prevalence of gastrointestinal parasites in bovines in and around Junagadh (Gujarat). J Parasit Dis 40:1174-1178. https://doi.org/10.1007/s12639-015-0644-6

29. Maitra A, Yadav CL, Sanjukta RK (2014) Seasonal prevalence of paramphistomosis in domestic ruminants in different agroclimatic zones of Uttarakhand, India. Asian Pac J Trop Dis 4:S748-S753. https://doi.org/10.1016/S2222-1808(14)60720-9

30. Marskole P, Verma Y, Dixit AK et al (2016) Prevalence and burden of gastrointestinal parasites in cattle and buffaloes in Jabalpur, India. Vet World 9:1214-1217. https://doi.org/10.14202/vetworld.2016.1214-1217

31. Mes THM, Ploeger HW, Terlou M et al (2001) A novel method for the isolation of gastro-intestinal nematode eggs that allows automated analysis of digital images of egg preparations and high throughput screening. Parasitol 123:309-

314. https://doi.org/10.1017/S0031182001008496

32. Mondal MAA, Islam MK, Jin $\mathrm{H}$ et al (2000) Examination of gastro-intestinal helminthes in livestock in grassland of Bangladesh. Korean J Parasitol 38:187-190. https://doi.org/10.3347/kjp.2000.38.3.187

33. National Population and Housing Census (NPHC) (2011) National Report. Government of Nepal National Planning Commission Secretariat Central Bureau of Statistics Kathmandu, Nepal November, 2012

34. Otranto D, Dantas-Torres F, Brianti E et al (2013) Vector-borne helminths of dogs and humans in Europe. Parasit Vectors 6:114. https://doi.org/10.1186/1756-3305-6-16

35. Rajakaruna RS, Warnakulasooriya KN (2011) Gastrointestinal parasites in dairy cattle in Kandy district in Sri Lanka. Annu Res J SLSAJ 11:92-99

36. Rashid MM, Hoque MA, Alim MA et al (2015) Prevalence of gastrointestinal parasites in Brahman crossbred cattle of Bangladesh. Livestock Res Rural Dev 27 (7)

37. Raza AM, lqbal Z, Jabbar A et al (2007) Point prevalence of gastrointestinal helminthiasis in ruminants in southern Punjab, Pakistan. J Helminthol 81:323-328. https://doi.org/10.1017/S0022149X07818554

38. Raza AM, Murtaza S, Bachaya HA et al (2010) Point Prevalence of Toxocara vitulorum in Large Ruminants Slaughtered at Multan Abattoir. Pak Vet J 30:242-244

39. Sahoo N, Mohanty TN, Samal S (2002) Prevalence of gastrointestinal helminthic infection among grazing and stall-fed cattle in a rainfed district of Orissa. J Vet Parasitol 16:61-62

40. Shirale SY, Meshram MD, Khillare KP (2008) Prevalence of gastrointestinal parasites in cattle of western Vidarbha region. Vet World 1:45

41. Shoriki T, Ichikawa-Seki M, Devkota B (2014) Molecular phylogenetic identification of Fasciola flukes in Nepal. Parasitol Int 63:758762. https://doi.org/10.1016/j.parint.2014.07.001

42. Soulsby EJL (1982) Helminths, Arthopods and Protozoa of Domesticated Animals. $7^{\text {th }}$ ed. BailliereTindall, London. 
43. Squire SA, Amafu-Dey H, Beyuo J (2013) Epidemiology of gastrointestinal parasites of cattle from selected locations in Southern Ghana. LRRD 25:29-34

44. Takeet MI, Badru OB, Olubgbogi E et al (2016) Prevalence of gastrointestinal parasites of cattle in Abeokuta, Ogun State, Nigeria. Nigerian J Anim Sci 18:158-165

45. Taylor MA, Coop RL, Wall RL (2007) Veterinary parasitology. $3^{\text {rd }}$ ed. Blackwell Publishing Ltd.

46. Thrusfield M (2005) Veterinary epidemiology ( $3^{\text {rd }}$ edn) Blackwell Science. United Kingdom, 158

47. Urquhart GM, Armour J, Duncan JL et al (1994) Veterinary Parasitology. Longman Scientific and Technical. 285

48. Wadhwa A, Tanwar RK, Singla LD et al (2011) Prevalence of gastrointestinal helminthes in cattle and buffaloes in Bikaner, Rajasthan, India. Vet World 4:417. https://doi.org/10.5455/vetworld.2011.417-419

49. Wang CR, Qiu JH, Zhao JP et al (2006) Prevalence of helminthes in adult dogs in Heilongjiang Province, the People's Republic of China. Parasitol Res 99:627-630. https://doi.org/10.1007/s00436-006-0219-7

50. Weatherhead JE, Gazzinelli-Guimaraes P, Knight JM et al (2020) Host immunity and inflammation to pulmonary helminth infections. Front Immunol11. https://doi.org/10.3389/fimmu.2020.594520

51. Yadav SK, Ahaduzzaman M, Sarker S (2015) Epidemiological survey of fascioliasis in cattle, buffalo and goat in Mahottari and Dhanusha, Nepal. J. Adv. Parasitol 2:51-56. https://doi.org/10.14737/journal.jap/2015/2.3.52.56

52. Zajac AM, Conboy GA (2012) Veterinary Clinical Parasitology. 8th ed. John Wiley \& Sons, Inc., UK. p3-170

\section{Tables}

Table 1 Overall prevalence of protozoan and helminth parasites in abandoned cattle $(n=100)$ and intensity of infection in terms of mean eggs/oocysts per gram (EPG/OPG) of feces

\begin{tabular}{|c|c|c|c|c|c|c|c|}
\hline \multicolumn{2}{|c|}{ Identified parasites } & \multirow[t]{3}{*}{$\begin{array}{l}\text { Prevalence } \\
(\%)\end{array}$} & \multicolumn{2}{|c|}{$\begin{array}{l}\text { Eggs/oocysts per gram of } \\
\text { feces }\end{array}$} & \multicolumn{3}{|c|}{$\begin{array}{l}\text { Intensity of infection in terms of egg/oocystper } \\
\text { gram (EPG/OPG) of faeces }\end{array}$} \\
\hline & & & Range & Mean \pm SD & Light & Moderate & Higher \\
\hline & & & & & $(50-799)(\%)$ & $(800-1200)(\%)$ & $(>1200)(\%)$ \\
\hline Protozoa & Eimeria & 27 & $\begin{array}{l}450- \\
1500\end{array}$ & $858.02 \pm 63.46^{\mathrm{a}}$ & $14(19.44)$ & $7(9.72)$ & $6(8.33)$ \\
\hline \multirow[t]{7}{*}{ Nematodes } & Ostertagia & 9 & $\begin{array}{l}100- \\
850\end{array}$ & $422.60 \pm 17.85^{b}$ & $6(8.33)$ & $3(4.16)$ & - \\
\hline & Haemonchus & 7 & $\begin{array}{l}200- \\
950\end{array}$ & $616 \pm 71.54^{c}$ & $3(4.16)$ & $4(5.55)$ & - \\
\hline & Trichostrongylus & 5 & $\begin{array}{l}150- \\
900\end{array}$ & $500 \pm 60.82^{c}$ & $2(2.77)$ & $3(4.16)$ & - \\
\hline & Capillaria & 3 & $\begin{array}{l}300- \\
900\end{array}$ & $544.44 \pm 19.24^{c}$ & $3(4.16)$ & - & - \\
\hline & Strongyle-type* & 3 & - & - & - & - & - \\
\hline & Trichuris & 2 & $\begin{array}{l}200- \\
1050\end{array}$ & $616.67 \pm 104.08^{c}$ & $1(1.38)$ & $1(1.38)$ & - \\
\hline & Toxocara & 1 & $\begin{array}{l}150- \\
200\end{array}$ & $183.33 \pm 28.86^{d}$ & $1(1.38)$ & - & - \\
\hline \multirow[t]{3}{*}{ Trematodes } & Fasciola & 11 & $\begin{array}{l}250- \\
550\end{array}$ & $408.33 \pm 62.51^{\mathrm{b}}$ & $11(9.72)$ & - & - \\
\hline & Paramphistomum & 4 & $\begin{array}{l}200- \\
500\end{array}$ & $379.16 \pm 7.21^{\mathrm{e}}$ & $4(5.55)$ & - & - \\
\hline & Total & 72 & & & $42(58.33)$ & $24(33.33)$ & $6(8.33)$ \\
\hline
\end{tabular}

*EPG not counted. Same superscript within the column are not significantly different $(P>0.05)$ in DMRT. Percentage of light, moderate and severe infection has been calculated out of total 72 infected abandoned cattle.

Page $8 / 11$ 
Table 2 Prevalence of GIPs based on the gender and breed of abandoned cattle

\begin{tabular}{lllll}
\multicolumn{2}{l}{ Cattle group } & No. of samples & Prevalence & $\chi^{2} / p$-value \\
\cline { 1 - 4 } Gender & Male & 57 & $42(73.68)$ & $\chi^{2}=0.0003$ \\
\cline { 2 - 4 } & Female & 43 & $30(69.76)$ & p-value $=0.986$ \\
\cline { 2 - 4 } & Total & 100 & $72(72)$ & \\
\cline { 1 - 3 } Breed & Local breed & 37 & $24(64.86)$ & \multirow{2}{*}{$\chi^{2}=0.1112$} \\
\cline { 2 - 4 } & Cross breed & 63 & $48(76.19)$ & p-value $=0.738$ \\
\cline { 2 - 3 } & Total & 100 & $72(72)$ &
\end{tabular}

Table 3 Prevalence of GIPs within different age groups of abandoned cattle

\begin{tabular}{|c|c|c|c|c|c|c|c|}
\hline Cattle type & Total & Female & Positive (\%) & Male & Positive (\%) & Total Positive (\%) & $\chi^{2} / p$-value \\
\hline Calf & 14 & 2 & $1(50.00 \%)$ & 12 & $5(41.67 \%)$ & $6(42.86 \%)$ & $\chi^{2}=12.562$ \\
\hline \multicolumn{7}{|l|}{ (0-1 Year) } & \multirow[t]{6}{*}{$p$-value $=0.02499<0.05$} \\
\hline Heifer & 17 & 0 & 0 & 17 & $13(76.47 \%)$ & $13(76.47 \%)$ & \\
\hline (1-3 Year) & & & & & & & \\
\hline Adult & 69 & 41 & $29(70.73 \%)$ & 28 & $24(85.71 \%)$ & $53(76.81 \%)$ & \\
\hline \multicolumn{7}{|l|}{ (>3 Years) } & \\
\hline Total & 100 & 43 & $30(69.77 \%)$ & 57 & $42(73.68 \%)$ & $72(72.00 \%)$ & \\
\hline
\end{tabular}

Table 4 Prevalence of GIPs in abandoned cattle based on the sampling sites 
Types of parasites

Positive cases (Prevalence \%)

\begin{tabular}{|c|c|c|c|c|c|c|c|c|c|}
\hline & & $\begin{array}{l}\text { Gaushala } \\
(n=30)\end{array}$ & $\begin{array}{l}\text { Balkhu } \\
(\mathrm{n}=20)\end{array}$ & $\begin{array}{l}\text { Budhanilkantha } \\
(\mathrm{n}=7)\end{array}$ & $\begin{array}{l}\text { Kirtipur } \\
(n=12)\end{array}$ & $\begin{array}{l}\text { Naksal } \\
(n=4)\end{array}$ & $\begin{array}{l}\text { Kalimati } \\
(n=18)\end{array}$ & $\begin{array}{l}\text { Jorpati } \\
(n=4)\end{array}$ & $\begin{array}{l}\text { Kalanki } \\
(n=5)\end{array}$ \\
\hline Protozoa & Eimeria & $8(26.67)$ & $4(20)$ & $3(42.85)$ & $\begin{array}{l}2 \\
(16.67)\end{array}$ & $2(50)$ & $\begin{array}{l}6 \\
(33.33)\end{array}$ & $1(25)$ & $1(20)$ \\
\hline \multirow[t]{7}{*}{ Nematodes } & Ostertagia & $3(10)$ & $2(10)$ & $1(14.28)$ & $\begin{array}{l}1 \\
(8.33)\end{array}$ & 0 & $\begin{array}{l}2 \\
(22.22)\end{array}$ & 0 & 0 \\
\hline & Haemonchus & $2(6.67)$ & $1(5)$ & 0 & $\begin{array}{l}1 \\
(8.33)\end{array}$ & 0 & $\begin{array}{l}2 \\
(22.22)\end{array}$ & 0 & $1(20)$ \\
\hline & Trichostrongylus & $1(3.33)$ & $1(5)$ & 0 & $\begin{array}{l}1 \\
(8.33)\end{array}$ & $1(25)$ & 0 & $1(25)$ & 0 \\
\hline & Capillaria & $1(3.33)$ & 0 & 0 & $\begin{array}{l}1 \\
(8.33)\end{array}$ & 0 & 0 & 0 & $1(20)$ \\
\hline & Strongyle-type & $1(3.33)$ & 0 & $1(14.28)$ & $\begin{array}{l}1 \\
(8.33)\end{array}$ & 0 & 0 & 0 & 0 \\
\hline & Trichuris & 0 & $1(5)$ & 0 & 0 & 0 & $\begin{array}{l}1 \\
(11.11)\end{array}$ & 0 & 0 \\
\hline & Toxocara & 0 & $1(5)$ & 0 & 0 & 0 & 0 & 0 & 0 \\
\hline \multirow[t]{3}{*}{ Trematodes } & Fasciola & $4(13.33)$ & $1(5)$ & 0 & $\begin{array}{l}2 \\
(16.67)\end{array}$ & 0 & $\begin{array}{l}2 \\
(22.22)\end{array}$ & $1(25)$ & $1(20)$ \\
\hline & Paramphistomum & $2(6.67)$ & 0 & 0 & $\begin{array}{l}1 \\
(8.33)\end{array}$ & 0 & $\begin{array}{l}1 \\
(11.11)\end{array}$ & 0 & 0 \\
\hline & Total & $\begin{array}{l}22 \\
(73.33)\end{array}$ & $\begin{array}{l}11 \\
(55)\end{array}$ & $5(71.78)$ & $\begin{array}{l}10 \\
(83.33)\end{array}$ & $3(75)$ & $\begin{array}{l}14 \\
(77.78)\end{array}$ & $3(75)$ & $4(80)$ \\
\hline
\end{tabular}

Table 5 Pattern of mixed infection of GIPs in abandoned cattle

\begin{tabular}{lll} 
Infection type & Combination of parasites & Number of cases (\%) \\
Duplet & Eimeria + Fasciola & $11(23.91)$ \\
\hline Eimeria + Paramphistomum & $6(13.04)$ \\
\hline Eimeria + Ostertagia & $9(19.57)$ \\
\hline Eimeria + Trichostrongylus & $4(8.70)$ \\
\hline Eimeria + Haemonchus & $2(4.34)$ \\
\hline Fasciola + Haemonchus & $3(6.52)$ \\
\hline Fasciola + Ostertagia & $2(4.34)$ \\
\hline Fasciola + Strongyle-type eggs & $2(4.34)$ \\
\hline Paramphistomum + Haemonchus & $1(2.17)$ \\
\hline Total & $40(86.95)$ \\
\hline Eimeria + Fasciola + Ostertagia & $2(4.34)$ \\
\hline Fasciola + Haemonchus + Trichostrongylus & $1(2.17)$ \\
\hline Trichostrongylus + Haemonchus + Capillaria & $2(4.34)$ \\
\hline Trichostrongylus + Trichuris. + Ostertagia & $1(2.17)$ \\
\hline Total & $6(13.04)$ \\
\hline Grand total & $46(63.89)$ \\
\hline
\end{tabular}

Page 10/11 


\section{Figures}

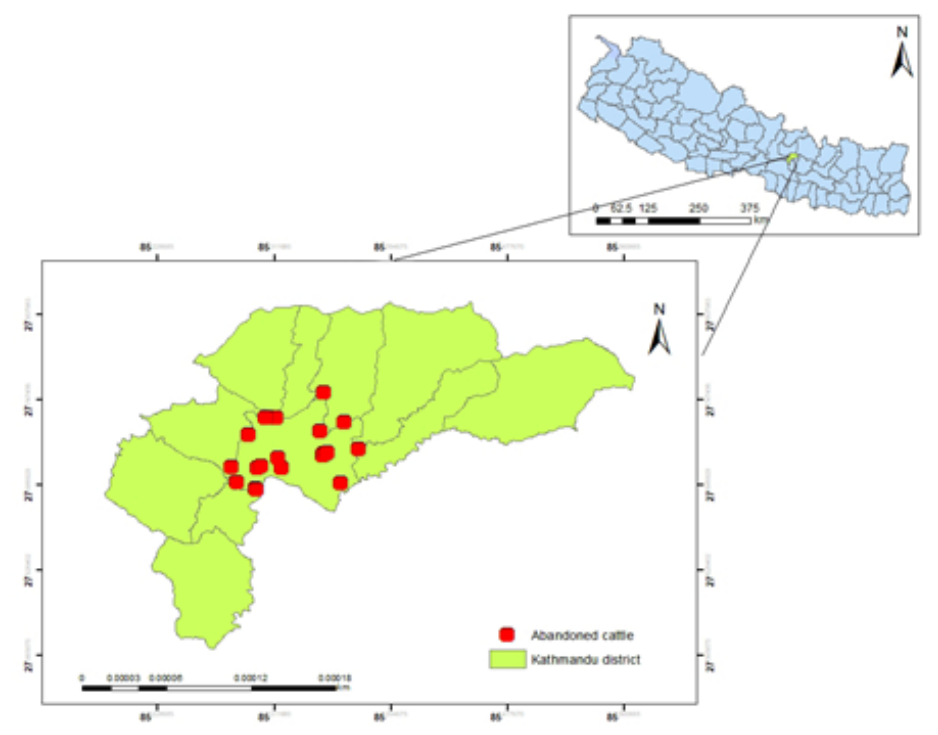

\section{Figure 1}

Map showing sampling sites.

\section{Figure 2}

Gastrointestinal parasites identified form abandoned cattle. A and B: Eimeria spp. (17.92-22.4um), C: Ostertagia spp. (64.96 × $35.84 \mu \mathrm{m})$, D: Haemonchus spp. $(73.92 \times 38.23 \mu \mathrm{m})$; E: Trichostrongylus spp. $(53.76 \times 39.21 \mu \mathrm{m})$, F: Capillaria spp. $(58.24 \times 24.7 \mu \mathrm{m}), \mathbf{G}$ and H: Strongyle-type $(58.24 \times 41.20 \mu \mathrm{m})$, I: Trichuris spp. $(67.2 \times 37.13 \mu \mathrm{m})$, J: Toxocara spp. $(56.0 \times 54.21 \mu \mathrm{m})$, K: Fasciola spp. $(156.8$ $\times 72.15 \mu \mathrm{m})$ and L: Paramphistomum spp. $(145.6 \times 71.68 \mu \mathrm{m})$. 